\title{
KAJIAN DRUG-RELATED PROBLEMS DAN GAMBARAN KUALITAS HIDUP PASIEN HEMODIALISIS RUTIN LANJUT USIA DI RSUP DR. SARDJITO YOGYAKARTA
}

\author{
Ndaru Setyaningrum*, Djoko Wahyono, I Dewa Putu Pramantara
}

Program Studi Apoteker FMIPA UII Yogyakarta

*e-mail: farmasi_ndaru@yahoo.co.id

\begin{abstract}
ABSTRAK
Pertumbuhan populasi lanjut usia secara global meningkat paling cepat diantara kelompok usia lain. Populasi lanjut usia berhubungan dengan penurunan fungsi ginjal dan berbagai komorbiditas akibat proses penuaan. Pasien lanjut usia dengan gagal ginjal kronik berisiko tinggi mengalami drug-related problem (DRP) sehingga berpengaruh terhadap kualitas hidup pasien. Penelitian ini dilakukan untuk mengetahui hubungan kejadian DRP dengan kualitas hidup pasien hemodialisis rutin lanjut usia. Penelitian cross sectional terhadap pasien hemodialisis rutin periode 22 Oktober 2012 22 Januari 2013. Kajian DRP berdasarkan data pengobatan kemudian ditelaah secara literatur dan wawancara pasien. Pengukuran kualitas hidup menggunakan kuesioner SF36. Penilaian kepatuhan dan efek samping obat masing - masing menggunakan Modified Morisky Scale dan Naranjo Scale. Karakteristik 38 subjek penelitian usia $<70$ tahun (24 pasien) dan $\geq 70$ tahun (14 pasien); jenis kelamin pria (26 pasien) dan wanita (12 pasien); lama hemodialisis < 8 bulan ( 8 pasien) dan $\geq 8$ bulan (30 pasien); penyerta DM (23 pasien) dan non DM (15 pasien). Kajian DRP 53 kejadian berupa interaksi obat (30 kejadian); ADR (8 kejadian); pemilihan obat kurang tepat (4 kejadian); gagal menerima obat (4 kejadian); dosis sub terapi (3 kejadian); terapi tanpa indikasi (2 kejadian); dosis berlebihan (1 kejadian); dan indikasi tanpa terapi (1 kejadian). Hasil pengukuran rerata kualitas hidup $\pm S D \quad(52,16 \pm 11,82) ; \quad P C S \pm S D$ $(44,52 \pm 13,91)$; dan MCS $\pm S D(60,27 \pm 14,00)$. Hasil analisis korelasi Pearson kualitas hidup dengan kejadian DRP bermakna tidak signifikan $(p>0,05)$. Penelitian ini tidak menunjukkan korelasi signifikan antara kejadian DRP dengan kualitas hidup pasien hemodialisis rutin lanjut usia.
\end{abstract}

Kata kunci : DRPs, hemodialisis, lanjut usia, kualitas hidup, RSUP Dr. Sardjito Yogyakarta

\section{ABSTRACT}

The growth of elderly population increase fastest among the other age group. The elderly population been related to decrease renal function and other comorbidity as consequence of aging. The elderly patient with chronic kidney failure on high risk of drug-related problem (DRPs) so can attribute to patient's quality of life (QoL). The aim of this study is to know how about corelation of DRPs event and QoL of elderly patient on routine hemodialysis. This is a cross sectional study about elderly patient on routine hemodialysis on period October $22^{\text {th }}$ 2012 - January $22^{\text {th }} 2013$. The study of DRPs based on medication list then been analyzed theoritically and interview to patient. The measuring of QoL use SF-36 questionaire. Assessment of adherence and drug side effect use Modified Morisky Scale and Naranjo Scale. There were 38 subjects analized, age $<70$ years old (24 patients) and $\geq 70$ years old (14 patients); gender men (26 patients) and women (12 patients); duration hemodialysis $<8$ months (8 patients) and $\geq 8$ months (30 patients); comorbidity DM (23 patients) and non DM (15 patients). There were 53 events DRPs consist of drug interactions (30 events); ADR (8 events); inproper drug selection (4 events); failure to receive drug (4 events); subtherapeutic dose (3 events); drug use without indication (2 events); overdose (1 event) and untreated indication (1 event). The result of mean QoL $\pm S D(52.16 \pm 11.82)$; $\mathrm{PCS} \pm S D$ (44.52 \pm 13.91$) ;$ and $\mathrm{MCS} \pm \mathrm{SD}$ $(60.27 \pm 14.00)$. The Pearson corelations of QoL and DRP event is not significant $(p>0.05)$. This study show not significant 
correlation between DRPs event and QoL of elderly patient on routine hemodialysis.

Keywords : DRPs, Dr. Sardjito Hospital Yogyakarta, elderly, hemodialysis, quality of life

\section{PENDAHULUAN}

Pertumbuhan populasi lanjut usia secara global meningkat paling cepat diantara kelompok usia lain. Jumlah penduduk lanjut usia di negara maju diperkirakan mencapai 30\% dari keseluruhan populasi pada tahun 2050 (Nobili, dkk, 2011). Seiring dengan peningkatan jumlah populasi lanjut usia maka prevalensi penyakit kronik berhubungan dengan usia seperti hipertensi dan penyakit ginjal kronik juga meningkat (Fischer dan O'Hare, 2010). Beberapa studi menyatakan bahwa prevalensi penyakit ginjal kronik meningkat seiring dengan jumlah usia (Zhang dan Rothenbacher, 2008; Stevens, dkk., 2010).

Pasien dengan gangguan fungsi ginjal sering mengalami perubahan parameter farmakokinetik seperti absorbsi obat, distribusi, ikatan protein, metabolisme dan ekskresi obat melalui ginjal (Hassan, dkk., 2009). Keadaan pasien lanjut usia dengan gagal ginjal kronik berisiko tinggi mengalami masalah berhubungan dengan pengobatan (Hajjar, dkk., 2007). Masalah yang berhubungan dengan pengobatan telah diketahui berhubungan dengan morbiditas, mortalitas, dan penurunan kualitas hidup (Cardone, dkk., 2010; Mahmoud, 2008). Kajian farmasis dalam pengobatan berhubungan dengan penurunan jumlah pengobatan dan frekuensi rawat rumah sakit (hospitalisasi), serta turut dalam menjaga kualitas hidup pasien (Nancy, dkk., 2011).
Penelitian ini dilakukan untuk mengetahui hubungan antara kejadian DRPs dengan kualitas hidup pasien hemodialisis rutin lanjut usia di RSUP Dr. Sardjito Yogyakarta.

\section{METODE PENELITIAN}

Penelitian ini merupakan penelitian cross sectional dengan pengambilan data secara prospektif. Subjek penelitian merupakan pasien hemodialisis rutin lanjut usia di unit dialisis RSUP Dr. Sardjito Yogyakarta periode 22 Oktober 2012 sampai 22 Januari 2013.

Pengambilan data dilakukan dengan metode wawancara dan penelusuran rekam medik. Jenis data yang diambil adalah data demografi pasien, profil pengobatan serta kualitas hidup pasien.

Pengukuran kualitas hidup menggunakan kuesioner SF-36. Penentuan DRP berupa pemilihan obat kurang tepat, pendosisan kurang tepat, dan interaksi obat potensial berdasarkan hasil studi pustaka. Sedangkan penelusuran DRP aktual berupa adverse drug reaction dan gagal menerima obat karena ketidakpatuhan masing-masing menggunakan Naranjo Scale dan Modified Morisky Scale.

\section{Pengolahan dan analisis data}

Kajian DRP dilakukan terhadap setiap pasien berdasarkan data profil pengobatan dan wawancara. Hasil kajian DRP kemudian dihitung secara numerik berdasarkan jumlah kejadian DRP setiap pasien. Pengolahan data kualitas hidup dilakukan dengan melihat skor hasil kuesioner masing- masing domain kemudian dihitung nilai rata-rata skoring keseluruhan setiap pasien. Analisis univariat 
dengan SPSS untuk mengetahui normalitas data untuk menentukan jenis pengujian selanjutnya. Uji $t$ dilakukan untuk mengetahui kemaknaan perbedaan rata rata skor kualitas hidup berdasarkan karakteristik subjek penelitian. Analisis korelasi pearson untuk mengetahui tingkat hubungan kejadian DRP dengan kualitas hidup pasien.

\section{HASIL DAN PEMBAHASAN}

\section{Kajian drug-related problems}

Hasil kajian drug-related problems menunjukkan terdapat 53 total kejadian
DRP. Kajian interaksi obat melalui penelusuran literatur Drug Interaction Fact Tatro (2011) terjadi paling dominan diantara jenis DRP lain. Pasien lanjut usia dengan penurunan fungsi fisiologis sangat rentan mengalami medication error akibat penggunaan berbagai obat untuk mengatasi komorbiditas (Midlov, dkk., 2009). Konsumsi berbagai macam obat meningkatkan risiko interaksi obat. Kejadian interaksi obat meningkat sekitar 6\%; 50\% dan 100\% berturut-turut pada pasien yang menggunakan 2; 5 dan 10 jenis pengobatan (Lin, 2003).

Tabel 1. Kajian drug-related problems subjek penelitian

\begin{tabular}{cccc}
\hline No & Jenis drug-related problems & Jumlah kejadian & Persentase (\%) \\
\hline 1 & Interaksi obat & 30 & 56,60 \\
2 & Adverse Drug Reactions & 8 & 15,09 \\
3 & Pemilihan obat kurang tepat & 4 & 7,55 \\
4 & Gagal menerima obat & 4 & 7,55 \\
5 & Dosis sub terapi & 3 & 5,66 \\
6 & Terapi tanpa indikasi & 2 & 3,77 \\
7 & Dosis berlebih & 1 & 1,89 \\
8 & Indikasi tanpa terapi & 1 & 1,89 \\
\hline \multicolumn{7}{r}{} & Total kejadian drug-related problems & 53 & 100 \\
\hline
\end{tabular}

Kejadian ADR menduduki peringkat kedua setelah interaksi obat dengan jumlah 8 kejadian (15,09\%). Seiring dengan pertambahan usia risiko kejadian adverse drug reaction (ADR) juga meningkat. Hal ini dipengaruhi oleh polifarmasi dan perubahan fisiologi sehingga mempengaruhi respon farmakokinetik farmakodinamik obat (Tangiisuran, dkk., 2009). Sebagian besar studi menunjukkan prevalensi kejadian ADR lebih tinggi pada pasien lanjut usia dibandingkan pasien dewasa (Mandavi, dkk., 2012). Suatu studi menunjukkan kejadian ADR pada pasien dialisis sebesar $20,7 \%$ dari keseluruhan masalah berhubungan dengan pengobatan (Manley, dkk., 2003).
Pemilihan obat kurang tepat untuk pasien lanjut usia merupakan masalah utama kesehatan dihubungkan dengan morbiditas dan mortalitas. Kemungkinan reaksi tidak dikehendaki akibat pemilihan obat tidak tepat juga berdampak pada peningkatan biaya kesehatan (Guaraldo, dkk., 2011). Kegagalan menerima obat pasien terjadi akibat kepatuhan rendah. Ketidakpatuhan terhadap regimen pengobatan merupakan permasalahan dalam manajemen terapi pasien gagal ginjal terminal (Schmid, dkk., 2009). 


\section{Kualitas hidup pasien hemodialisis rutin lanjut usia}

Nilai rerata kualitas hidup dimensi MCS $\pm S D \quad(60,27 \pm 14,00) \quad$ lebih besar dibandingkan dimensi PCS \pm SD $(44,52 \pm 13,91) \quad$ (Tabel 2). Hal ini menunjukkan fungsi mental subjek penelitian lebih baik dibandingkan fungsi fisik. Hasil ini sesuai dengan studi jurnal bahwa secara umum nilai kualitas hidup pasien lanjut usia lebih rendah dibandingkan pasien lebih muda terutama terkait dimensi fisik (Lin, dkk., 2003; Apostolou, 2007).

Hasil pengukuran rerata skor kualitas hidup pada kelompok pasien usia kurang dari 70 tahun sedikit lebih baik dibanding kelompok usia 70 tahun ke atas meskipun tidak berbeda signifikan ( $p>0,05)$ (tabel 3). Hasil ini sesuai dengan studi oleh Hairi, dkk., (2012) bahwa penurunan fungsi fisik, ketidakmampuan mobilitas dan keterbatasan fungsional meningkat seiring pertambahan usia. Penurunan fungsi fisik sebagai salah satu komponen kualitas hidup juga berdampak terhadap penurunan kualitas hidup secara keseluruhan.

Perbedaaan rerata kualitas hidup pada jenis kelamin pria sedikit lebih baik dibandingkan wanita meskipun tidak berbeda signifikan $(p>0,05)$ (tabel 3$)$. Hasil ini sesuai dengan jurnal Seica, dkk., (2009) skor kualitas hidup pada subjek penelitian wanita lebih rendah dibandingkan pria. Hal ini dapat dijelaskan oleh tanggung jawab domestik wanita lebih berat dan menimbulkan tekanan dibandingkan pria. Kekuatan fisik pria lebih baik dibanding wanita juga merupakan salah satu faktor dalam komponen penilaian kualitas hidup.

Perbedaan rerata kualitas hidup kelompok pasien dengan kejadian DRP dan tanpa DRP pada tabel 3 menunjukkan hasil berlawanan dengan studi Celin (2012); Lyra, dkk., (2007); dan Ernst, dkk., (2003). Kejadian drug-related problem meningkatkan morbiditas dan mortalitas pasien serta menurunkan kualitas hidup (Celin, 2012). Studi lebih mendalam dengan mengkaji jenis DRP potensial dan aktual serta mengikuti outcome klinis pasien akibat kejadian DRP dengan subjek penelitian lebih besar perlu dilakukan untuk memperoleh hasil lebih representatif.

Tabel 2. Nilai rerata kualitas hidup domain fisik dan mental

\begin{tabular}{llll}
\hline Domain SF-36 & Mean domain \pm SD & Mean \pm SD & \\
\hline Physical function (PF) & $59,08 \pm 23,79$ & & \\
Role physical (RF) & $9,87 \pm 17,95$ & Mean PCS \pm SD $=$ & \\
Bodily pain (BP) & $65,85 \pm 34,35$ & $44,52 \pm 13,91$ & Mean QoL $\pm S D=$ \\
General health (GH) & $43,29 \pm 9,88$ & & $52,16 \pm 11,82$ \\
Role emotional (RE) & $20,17 \pm 27,44$ & & \\
Vitality (VT) & $73,55 \pm 16,31$ & $60,27 \pm 14,00$ & \\
Mental health (MH) & $83,89 \pm 12,07$ & \\
Social function (SF) & $63,49 \pm 21,03$ & \\
\hline Keterangan : PCS (physical component score); MCS (mental component score)
\end{tabular}

Keterangan : PCS (physical component score); MCS (mental component score) 
Tabel 3. Nilai rerata kualitas hidup berdasarkan karakteristik pasien

\begin{tabular}{llll}
\hline Karakteristik pasien & Kategori & Mean QoL \pm SD & Signifikansi uji t \\
\hline Usia & $60-69$ tahun & $55,01 \pm 11,51$ & 0,050 \\
\multirow{2}{*}{ Jenis kelamin } & $\geq 70$ tahun & $47,27 \pm 11,07$ & \\
\multirow{2}{*}{ Kejadian DRP } & Pria & $52,33 \pm 10,51$ & 0,897 \\
& Wanita & $51,78 \pm 14,79$ & \\
& Tidak terjadi DRP & $46,37 \pm 12,69$ & 0,052 \\
Keterangan : QoL (quality of life) & Terjadi DRP & $53,79 \pm 9,52$ & \\
\end{tabular}

\section{Analisis korelasi pearson}

Hasil analisis korelasi pearson antara

kualitas hidup dengan kejadian DRP

menunjukkan nilai positif 0,074 tidak

bermakna $(p>0,05)$.

\section{KESIMPULAN}

Hasil penelitian ini menunjukkan tidak ada korelasi signifikan antara kejadian DRP dengan kualitas hidup pasien hemodialisis rutin lanjut usia.

\section{DAFTAR PUSTAKA}

Apostolou, T., 2007, Review Article: Quality of life in the elderly patients on dialysis. Int Urol Nephrol ;39:679-683

Cardone, K.E., Bacchus, S., Assimon, M.M., Pai, A.B., Manley, H.J., 2010, Medication-related Problems in CKD. Advances in Chronic Kidney Disease. Vol.17:5.pg404-412

Celin, A.T., Seuma, J., Ramesh, A., 2012, Assessment of drug related problems in stroke patients admitted to a South Indian tertiary care teaching hospital. Indian Journal of Pharmacy Practice;5(4).pp28-33

Ernst, M.E., lyer, S.S., Doucette, W.R., 2003, Drug-related problems and quality of life in arthritis and low back pain sufferers. Value Health;6(1):51-8

Fischer, M.J., dan O'Hare, A.M., 2010, Epidemiology of hypertension in the elderly with chronic kidney disease.Adv Chronic Kidney Dis.Jul;17(4):329-40
Guaraldo, L., Cano, F.G., Damasceno, G.S., Rozenfeld, S., 2011, Inappropriate medication use among the elderly:a systematic review of administrative databases.BMC Geriatrics;11:79.pp110

Hairi, N.N., Hiong, T.G., Bulgiba, A., Mudla, I., 2012, Physical Function in Older People, Geriatrics, Prof. Craig Atwood (Ed.), ISBN: 978-953-51-0080-5, InTech, Available from: http://www.intechopen.com/books/geri atrics/physical-function-in-olderpeople, diakses tanggal 8 April 2013

Hajjar, E.R., Cafiero, A.C., Hanlon, J.T., 2007, Polypharmacy in Elderly Patients. AmJ Geriatr Pharmacother:5:345-351

Hassan, Y., Al-Ramahi, R.J., Aziz, N.A., Ghazali, R., 2009, Review Articel: Drug Use and Dosing in Chronic Kidney Disease. Ann Acad Med Singapore;38:1095-103

Lin, A., Qian, J., Yao,Q., Gu, A., 2003, Quality of life in elderly continuous ambulatory peritoneal dialysis patients. Perit Dial Int;23(S2):S95-S98

Lin, P., 2003, Drug interactions and polypharmacy in the elderly. The Canadian Alzheimer Disease Review.Pp.10-14

Lyra, D.P., Kheir, N., Abriata, J.P., da Rocha, C.E., Dos Santos, C.B., Pelá, I.R., 2007, Impact of Pharmaceutical Care interventions in the identification and resolution of drug-related problems and on quality of life in a group of elderly outpatients in Ribeirão Preto (SP), Brazil. Ther Clin Risk Manag.;3(6):989-98

Mahmoud, M.A., 2008, Drug therapy problems and quality of life in patient with chronic kidney disease, Tesis, M.Sc., Universiti Sains Malaysia 
Mandavi, D'Cruz, S., Sachdev, A., Tiwari, P., 2012, Adverse drug reactions \& their risk factors among Indian ambulatory elderly patients. Indian $J$ Med Res;136,pp 404-410

Manley, H.J., Drayer, D.K., Muther, R.S., 2003, Research article Open Access Medication-related problem type and appearance rate in ambulatory hemodialysis patients. BMC Nephrology ;4:10.pp 1-7

Midlov, P., Eriksson, T., Kragh, A., 2009, Drug-related problems in the elderly, Springer Dordrecht Heidelberg London New York

Nancy, A.M., 2011, Polypharmacy and medication-related complications in the chronic kidney disease patient, Current Opinion in Nephrology \& Hypertension; 20(5).p492-497

Nobili, A., Garattini, S., Mannucci, P.M., 2011, Review: Multiple diseases and polypharmacy in the elderly: challenges for the internist of the third millennium. Journal of Comorbidity; :28-44

Schmid, H., Hartmann, B., Schiffl, H., 2009, Adherence to prescribed oral medication in adult patients undergoing chronic hemodialysis: A critical review of the literature. Eur $J$ Med Res.14: 185-190

Seica, A., Segall, L., Verzan, C., Vaaduva, N., Madincea, M., Rusoiu, S., dkk., 2009, Factors affecting the quality of life of haemodialysis patients from Romania: a multicentric study. Nephrol Dial Transplant;24: 626-629

Stevens, L.A., Li, S., Wang, C., Huang, C., Becker, B.N., Bomback, A.S., dkk., 2010, Prevalence of CKD and Comorbid Illness in Elderly Patients in the United States: Results From the Kidney Early Evaluation Program (KEEP). American Journal of Kidney Diseases, Vol 55(3),Suppl 2.March: pp S23-S33

Tangiisuran, B., Wright, J., Van der cammen, T., Rajkumar, 2009, Adverse drug reactions in elderly: challenges in identification and improving preventative strategies.Age and Ageing; 38: 358-359
Tatro, D.S., 2011, Drug Interactions Fact : The authority on drug interactions. Wolter Kluwer Health Facts \& Comparisons

Zhang, Q., dan Rothenbacher, D., 2008, Prevalence of chronic kidney disease in population-based studies: Systematic review. BMC Public Health.8:117 